\title{
Iter-years dynamic of Juniperus phoencea $L$. matorral in the North-Eastern Mediterranen coast of Morocco.
}

\author{
Mehdi Boumediene ${ }^{1}{ }^{*}$,NargisSahib ${ }^{1}$, Malika Abid $^{1}$, Mohamed Addi ${ }^{1}$ AtikaMihamou ${ }^{1}$, Hana Serghini- \\ Caid $^{1}$, and Ahmed Elamrani ${ }^{1}$ \\ ${ }^{1}$ Laboratoire d'Amélioration de la Production Agricole, Biotechnologie et Environnement \\ (LAPABE). Departement of biology. Faculty of science. Mohamed I University. BP 717, BV \\ Mohammed VI 60500, Oujda, Maroc
}

\begin{abstract}
In the North-Eastern Mediterranen coast of Morocco, the establishment of seaside resorts built as part of the Plan Azur, substantially degraded the coastalmatorral of Juniperusphoenicea L. Nonetheless, the speciesremains an important resource for the ecological balance. The estimation of the changes in land cover is a suitable method to evaluate the degradation rate of the matorral. The aim of the current study is towarn about the degradation of $J$. phoeniceain Saidia coastline by quantifying the inter-years dynamic of $J$. phoeniceamatorralin 1965 (before the Plan Azur) in 2004 and 2021(after the Plan Azur). Estimation of changes in matorral cover rate was achieved by photo-interpretation. Analysis indicates that $J$. phoeniceamatorral ecosystem of Saidia has been affected by a drop of $63 \%$ in land area, over a period of time not exceeding 17 years. Currently the picture of the coastal matorral of J. phoenicea is rather bleak; the vulnerability of this valuable resource has prompted us to raise the alarmin order to preserve remaining up shrubs to the present time.
\end{abstract}

\footnotetext{
*Corresponding author: Boiumedienne.mehdi@ump.ac.ma
} 


\section{Introduction}

After the launch of the Plan Azur2002/Horizon 2010, and its revised and complementary plan Vision 2020 [1]tourism activities in the coastal areas of Morocco are permanently enlarging,butnegatively impactingcoastal naturalecosystems [2], hence leading to loss of habitats and species.Located in the north-eastern Mediterranean part of Morocco in the coastline between the deltaic estuary of the Moulouya river classified as SIBE and the Saidia city, the gigantic tourism project MediterraneaSaidia (SaidiaRessorts: La perle bleu) is one out of the six costal tourist project listed in Plan Azur.Since its launch in 2009, degradation of the coastal matorral ecosystem of Juniperusphoenicea L is obvious along the shoreline (Photo. 1), as the 713-hectares tourist project required the destruction of the coastal dune system, thus the vegetation of the dune system was eradicatedat the same time. (Figure1). The degradation of the matorral was deepened further with the excessive extraction of sand and the urban encroachment of Saidia city. Based on its high biodiversity and the number of found habitats, Saidiacostalineis considered as a high value habitat, it houses the estuary of the longest river in Morocco" Moulouya River", it is a site of biological and ecological interest "SIBE" includingendemic and rare plant species, with roughly 86 endangered species including $J$. phoenicea [4]. At the present time $J$. phoeniceamatorral in Saidia coastline area is threatened, and its functions are altered. Neither restoration strategies, nor sustainable management have started so far for its conservation. The aim of the current study is towarn about the degradation of $J$. phoeniceain Saidia coastline throughquantifying the inter-years dynamic of $J$. phoeniceamatorral,locating and delineating remaining shrubs of JuniperusphoeniceaLin 2021 along the shoreline by a ground data approach. The study will conclude by suggesting strategies for conservation and restoration of the matorral.
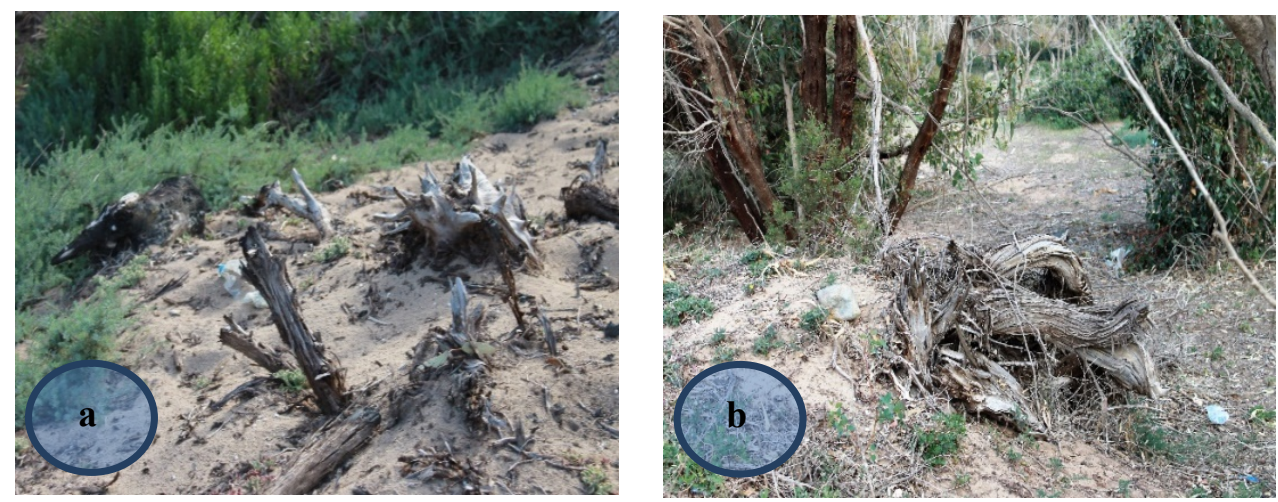

Photo 1: (a) destruction of vegetation (b) uprooting long-lived shrub of Juniperusphoenicea L

\section{Materials and methods}




\subsection{Study area}

The matorral of Juniperusphoenicea L. of Saidia coastline located in the northeasternmediterannen coast of Morocco. The region lies between latitudes 35 $5^{\prime}$ and $35^{\circ} 6^{\prime}$ north and longitudes $2^{\circ} 14^{\prime}$ and $2^{\circ} 19$ west. (Figure 1 ). Climateof the coastline is of a dry Mediterranean type with marine influences..The average temperature is $15.8^{\circ} \mathrm{C}$, with temperate winter $\left(11.1^{\circ} \mathrm{C}\right.$ in January) and high temperature in the summer $\left(22.3{ }^{\circ} \mathrm{C}\right.$ in August). Mean precipitation is $319 \mathrm{~mm}$ in Saidia city, highest precipitation occurs in winter (November/January). Summer drought is severe, with no rains during summer (July /August), and scarce rainfall in September.
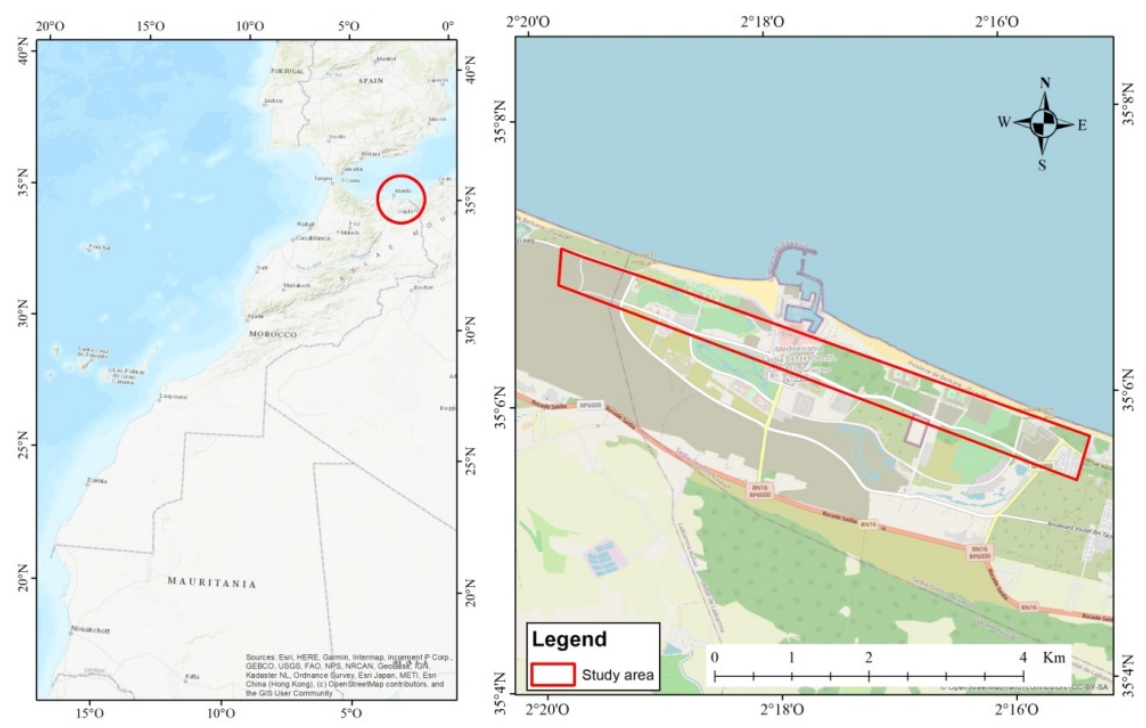

Fig.1.thestudy area.

\subsection{Data processing}

Previousextension of the shoreline vegetation (Tazegraret forest) along coastline of Saidia was based on topographic map dated 1965, (scale: 1/50 000), performed using the software "geographic information system "ARCSIG 10.8" tools. The inter-years dynamic of the matorral, was shown by a comparison of current and past satellite imagery from Google Earth in 2004 (one yearafter Azur Plan) and 2021(11 years after the Azur plan) (Table 1) within the total extend of 31 ha treated with "ARCGIS 10.8" software tools. To map of current distribution of $J$. Phoenicea shrubs along Saidia coastline, was firstly performed with geographic positioning coordinate database within the total extent of the matorral (31 ha area).The shrubs were located and delineated by walking along the shoreline with a GPS receiverusing a "MOBILE TOPOGRAPHY" smart application. Secondly a digital map was performed using the software "geographic information system "ARCSIG 10.8". Was also listed the numbers of regenerations and stumps, spontaneous regenerations young trees, resulting from natural seeding, layering or sprouting from root systems.To assess the vegetation in the ancient remains of the forest a comparison of 
current and past satellite imagery from Google Earth (in 2004 and 2021) treated with "ARCGIS 10.8" software tools was performed.

Table 1: Details of used documents.

\begin{tabular}{|c|c|c|c|}
\hline $\begin{array}{c}\text { Year and } \\
\text { document } \\
\text { type }\end{array}$ & Source & $\begin{array}{c}\text { Scale/resolu } \\
\text { tion }\end{array}$ & Uses \\
\hline $\begin{array}{c}\text { Topographic } \\
\text { map dated } \\
1965\end{array}$ & $\begin{array}{c}\text { Berkan } \\
\text { province }\end{array}$ & $1 / 50000$ & $\begin{array}{c}\text { Old extension } \\
\text { of coastline }\end{array}$ \\
\hline $\begin{array}{c}\text { Image dated } \\
2004\end{array}$ & $\begin{array}{c}\text { Google } \\
\text { Earth }\end{array}$ & $40 \mathrm{~cm}$ & $\begin{array}{c}\text { Inter-years } \\
\text { dynamic of } \\
\text { Juniper shrubs }\end{array}$ \\
\hline $\begin{array}{c}\text { Image dated } \\
2021\end{array}$ & $\begin{array}{c}\text { Google } \\
\text { Earth }\end{array}$ & $20 \mathrm{~cm}$ & $\begin{array}{c}\text { Inter-years } \\
\text { dynamic of } \\
\text { Juniper shrubs }\end{array}$ \\
\hline
\end{tabular}

\section{Results and discussion}

\subsection{Most Probablefloristiccomposition \& plants associations}

Data about ancient floristic composition of the forest of Tazegraretare fragmentary.Investigation about flagship plant species and floristic composition before the establishment of tourist project is deduced from following studies "le Plan Directeur des Aires Protégées du Maroc (AEFCS 1996)[5]; MedWetCoast-Maroc2003 [6], completed by "Ramsar consultative mission 2010[3], Projet FEM/Banquemondiale (GIZC P121271) 2012" [7].None of these studies provides an exhaustive analysis on the ancient vegetation of the coastline of Saidia, the species cited are based on our direct observations, with an extrapolation from the literature.The overall number of Taxa found is 131 representing 43 families classified in (Table 2). They are grouped into 3 large plant formations (sand dunes, Sansouire with Arthrocnemumet Sarcocornia, ripisylve with Tamarixcanariensiswilldand Tamarixboveana Bunge), On the Sand dunes was recorded the main following plants association: (a) association of OtanthoammophiletumaustralisJ.M. Gehu, Rivas-Martinez \& R.TX ; in [7], occupies small, mobile dunes and white sand dunes exposed to the sea winds.(b) association of Climatidicirrhosae-juniperetumlyciaeBarbero et al. 1981 [8], which grows behind Otantho-ammophiletumoften following it directly on the fixed gray dunes. The area is of Thermoméditerranan vegetation série type, it is under semiarid with temparate winter, which corresponds to coastal population of J. Phoenicea. Juniperusphoniceasubsp. lycia:,Sous-série of Rhamnusoeloides: thatcorrespond toRhamnorotundifolijuniperetumturbinatae [9].The subspecies lycia extending from Essaouira to the coastline of Saidia, covers the sandy dunes, semi-arid bioclimate and warm sub-humid to temperate bioclimate on soft sandy substrate [10] 


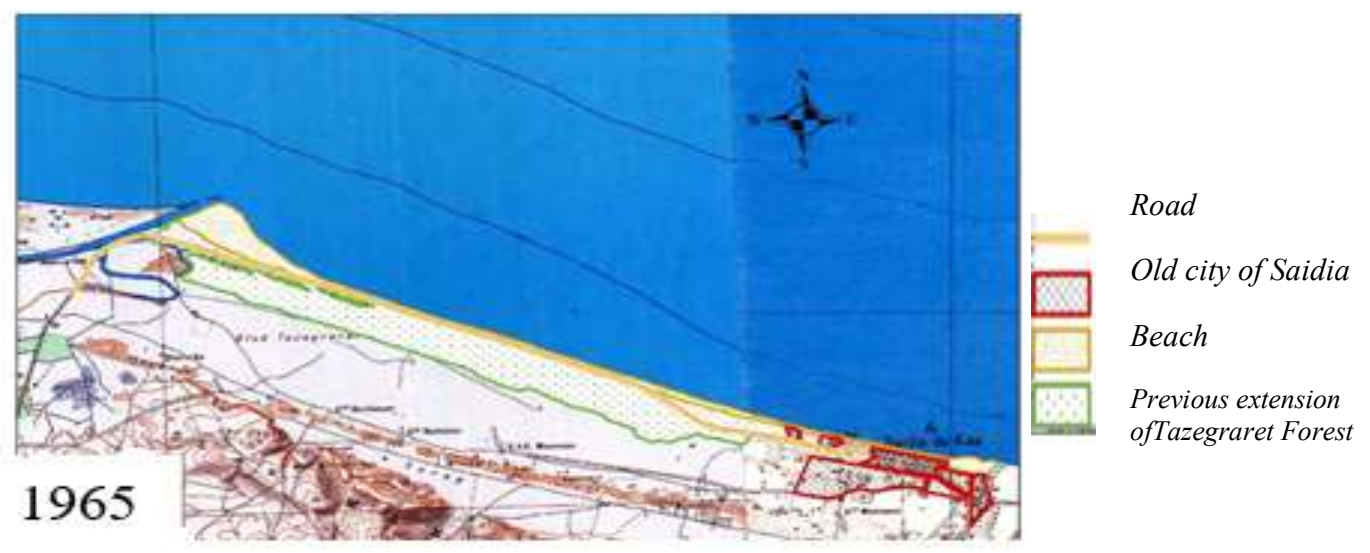

Fig. 2. Topographic map dated 1965, acquired from municipality of Berkane, showing old extension of Tazegraret forest along coastline of saidia, reflects the fatality of the vegetation losses (scale: $1 / 50000)$.

Table 2: Status of conservation of the total taxa recorded

\begin{tabular}{lcc}
\hline $\begin{array}{l}\text { Status of } \\
\text { conservation }\end{array}$ & $\begin{array}{c}\text { Number of } \\
\text { species }\end{array}$ & $\begin{array}{c}\text { Number of } \\
\text { families }\end{array}$ \\
\hline Endemic taxa & 13 & 7 \\
Rare taxa & 6 & 5 \\
Threatened & 3 & 3 \\
Remarkable & 89 & 37 \\
\hline Total & 111 & 43 \\
\hline
\end{tabular}

\subsection{Analyse of state of Juniperusphoenicea L.matorral in Saidia coastline}

3.2.1 Inter-years dynamic of Juniperusphoenicea L. matorral 
The inter-years dynamic (between 2004 and 2021) of the Juniperusphoenicea Lmatorralin Saidia coastline isof regressive trend (Figure3). Comparison current and past satellite imagery analysis from Google Earth on 2004 and 2021within the total extent of 31 hectares area showees a strong reduction from 155 hectares in 2004 to 57 hectares in 2021, meaning a loss of 98 hectares (red color). Has risen is $63 \%$ in a period of time not exceeding17 years.Juniperusphoenicea L matorrals represent the late successional stage of the sandy dune of the coastline area in Saidia. In a floristic composition view, it is the most original formation of the shoreline.Currently it corresponds to the last representative matorral of sandy dunes on the Moroccan Mediterranean coast. A major problem it has to cope with is the combined action of anthropogenic pression e.g.urban development, water pumping, and natural pression e.g. high variability of inter-annual precipitation, decrease in precipitation amount, reduction of groundwater recharge rate, aggressiveness of hydrodynamic agents that lead to a huge degradation of shrubs. Threatened after vegetation eradication, a number of 18 species of birds are nowadays threatened of extinction,tourist project has already exterminated thousands of Greek turtles and Chalcidae(species closely linked to this ecosystem and listed only in 4 regions of the

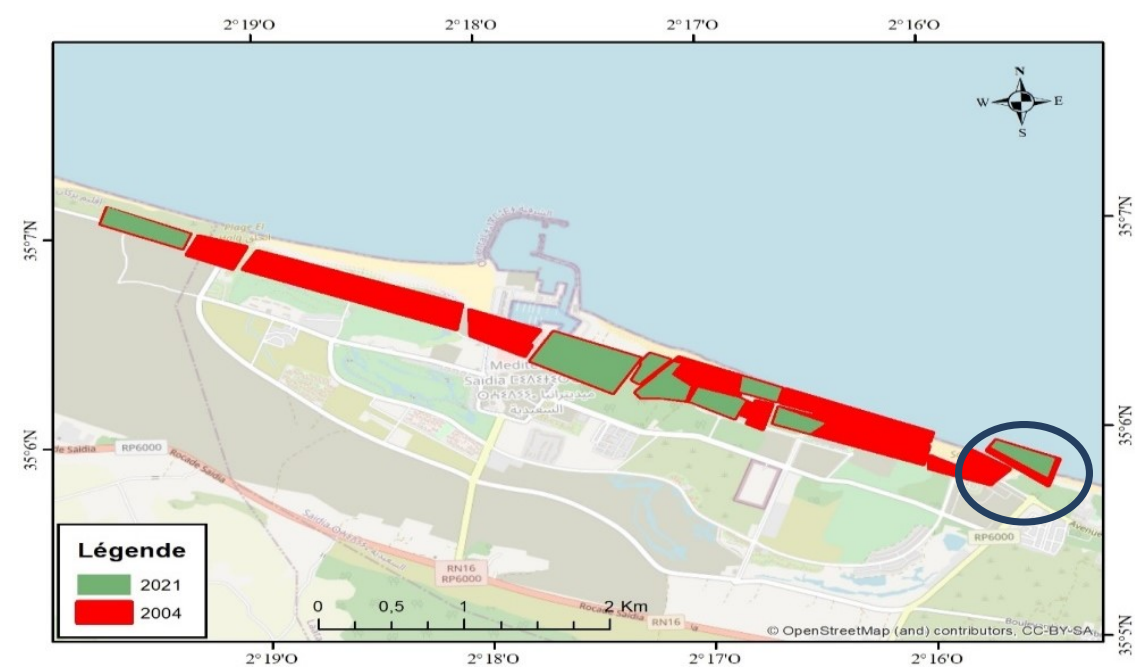

world). [6].

Fig. 3. Inter- years dynamic (year 2004 red color area) and (year 2021 green color) of the Juniperusphoenicea Lmatorral in Saidia coastline. The circled part is the eastern part of the ancient forest subject of Figure. 5 map.

\subsubsection{Current distribution of J. phoenicea along Saidia coastline}


Amongst1233 counted shrubs, 1072 are in good condition when 96 are dead. Shrubs arecurrently covering an area of about $31 \mathrm{ha}$, spread over a distance of $7 \mathrm{~km}$, from the city of Saidia until the site of biological and biological interest "SIBE" at the mouth of MoulouyaRiver(Figure4). Total of 113 new vegetative regenerations was counted, while 48 shrubs found in slops regenerated from seedlings. The mean habitat threat is not only the weak regeneration mechanisms, butdirect destruction of the population and its segmentation in distanced patchs with large disconnections in between (Figure 4). The isolation of the shrubs interrupts ecological processes such as dispersion of seeds. The study enable us to quantify the destruction effects on the Juniper shrubs on Saidia shoreline, given that shrubs fell and uprootingare amongst the most important risks in Saidia (Photo 1). However, the species is rustic and resistant, with little specific ecological demands; it survives at low precipitation $200-400 \mathrm{~mm}$, it occupies a wide range of environments between the coastal sandy dunes to the mountain tops[11].

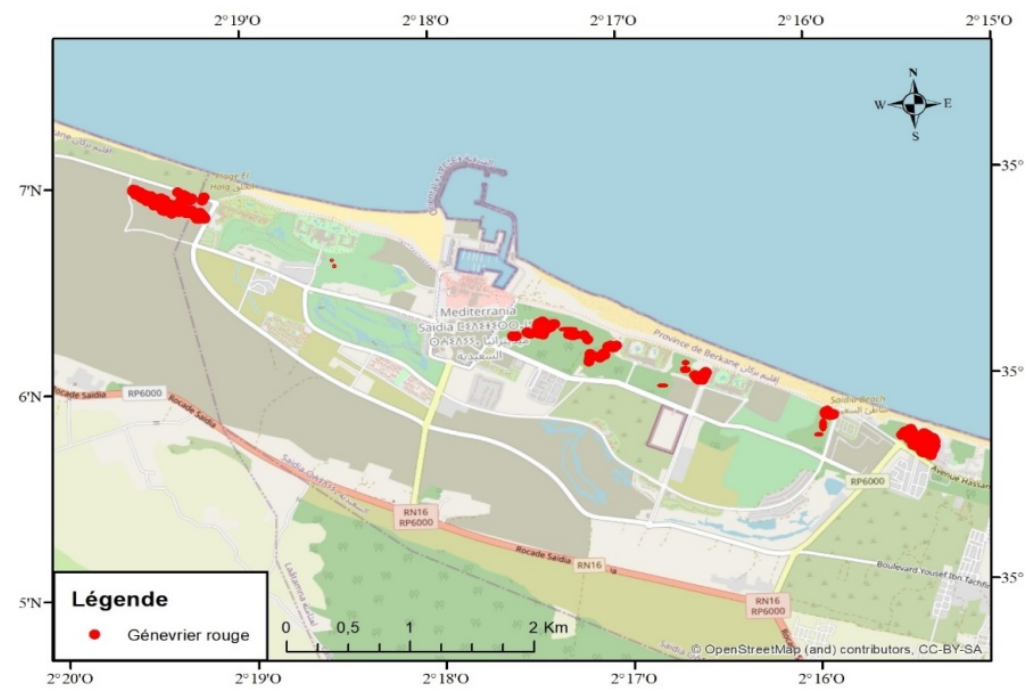

Fig.4.Located and delineated shrubs of JuniperusphoeniceaLin 2021 along the shoreline.

In Saidia coastline, the shrub is strongly withstanding the intense effect of coastal environmental stresses, such as salt spray deposition, sand mobility, and low water availability and may be considered stress-tolerant species[12]. The previous cited values give $J$. phoenicea an extreme importance in preserving the ecological balance within Saidia sandy dunes. Juniperusphoenicea L, it is indeed the best native species for future restoration programs.The shrub is native to the Northern Mediterranean and NorthAfrica[13].Juniperusphoenicea $\mathrm{L}$ is distinguished by the red color of its galbules, by its branched and less powerful port and the bushy appearance of its cylindrical branches $J$. phoeniceaisin Morocco is confined in the dunes of the Mediterranean and Atlantic coasts, in the mountains of the Middle and High Atlas and Rif. The shrub is experiencing two types of treats. On one hand human-induced threat such as water scarcity [2]; On the other 
hand, the current climatic changes that have almost affected the shorline zone causing profound changes at the mouth of the Moulouya river manifested by a remarkable retreat of the coastline[4]. The environmental risk predicted with climate change scenarios demonstrated that suitable environmental conditions for $J$. phoeniciaare going to change in a way that triggers spatial in species geographic distribution range is expected to occur latitudinally northward and longitudinally eastward[14].

\subsubsection{Threat includes parts of the matorral out of Azur plan project}

The analysis of the circled part (Figure 4), is the eastern part of ancient forest out of Azur plan projectconsidered as less threatened area.The analysis of vegetation dynamics shows an increase in the area of bare land, as it increased from $37,342 \mathrm{~m}^{2}$ in 2004 to $61,662 \mathrm{~m}^{2}$ in 2021. While the covered area with vegetation reached $54,443 \mathrm{~m}^{2}$ in 2004 , it decreased in 2021 to $30,103 \mathrm{~m}^{2}$, with a rate of deterioration of $45 \%$. This drop is related to an absence of any compensatory measure towards the coastline and its ecological values, the impact of planned facilities e.g. Buildings, golf courses, marina, water withdrawals from the Moulouya; protection channel against floods, bypass road, have accelerated the decline of biodiversity.

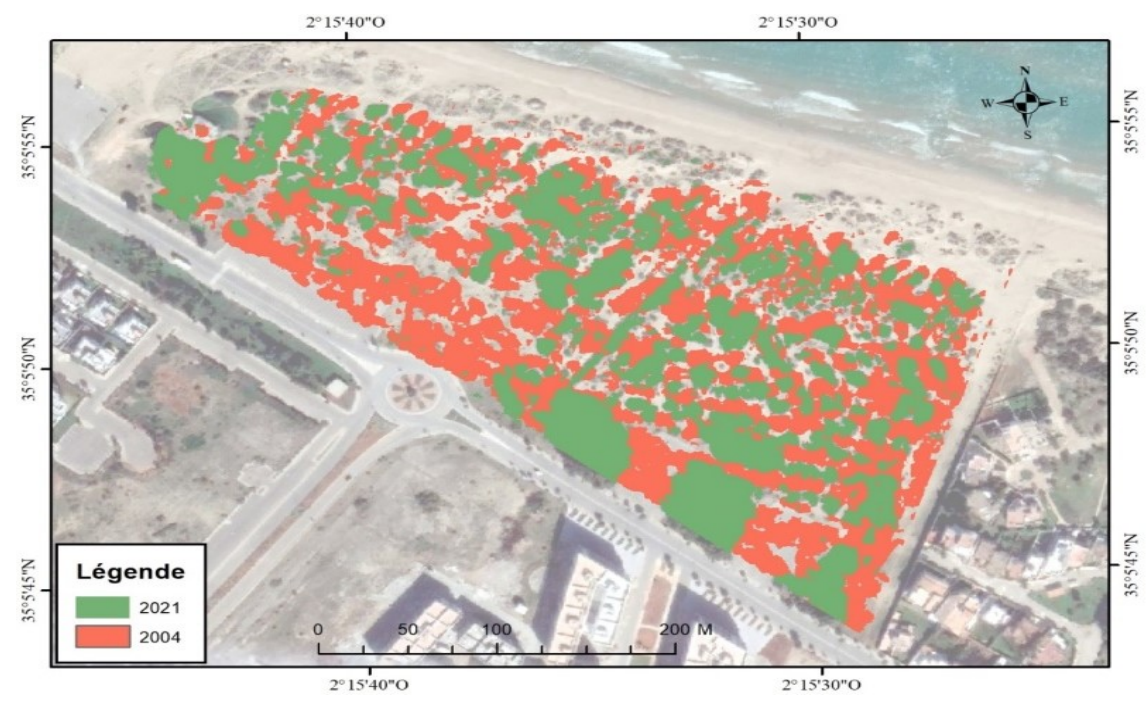

Fig. 5.Inter-years dynamic (2004 red color area) and (2021 green color area) of the vegetation in the eastern end of Saidia coastline.

\subsection{Strategies for conservation and restoration of the matorral}

The United Nations General Assembly declared 2021 to 2030 as the decade of ecosystem restoration. Hence conservation and restoration measures of coastal dunes in Saidia, are 
urgent in the current context of growing environmental awareness and concern for the future. When well-managed coastline dunes systems can harbour a great deal of biodiversity, landscapes of heritage value, associated with socio ecological consideration must be included for effective restoration and sustainability (e.g.integrated coastal zone management initiative ICZM). The main targets of coastal dune restoration are: (a) to avoid a loss of biodiversity, especially of rare and endemic species [15] (b) to avoid the encroachment of invasive species [16] that have been considered a major problem to be resolved. Given its ecological values JuniperusphoeniceaL. is among the native species that can stabilise vegetation recovery of coastal dunes e.g. Conservation Program of Maritime Juniper Woodlands in Andalucia[17]. Planting J. phoenicea shrubs is necessary to prevent erosion of sandy dunes, and sustain natural resource management. The high level of degradation of JuniperusphoeniceaL. is accentuated by a difficult random natural regeneration or natural rejection of sprouts; hence the majority of populations are represented by old shrubs. Yet to cope with is regeneration under controlled conditions as an alternative for conservation and sustainable uses. The real obstacle to regeneration of $J$. phoenicea is the difficulty of seeds germination due to dormancy phenomena. Failures to master regeneration techniques have always been an obstacle.

\section{Acknowledgment}

We are grateful to Pr. Sbai A. and Mr. Omar Mouadilifor their remarkable help.

\section{References}

1. ELeroux, A. Hmioui... Maghreb - Machrek 2019/1 (N239), (2019)

2. V Tekken, L. Costa,J.P. Kropp, Increasing pressure, declining water and climate change in north-eastern Morocco. J.Coa. Cons17(2013)

3.P. Triplet, M. Dakki, I.Cherkaoui, M. J de Lope, A. Dufour, Mission consultative Ramsar - Rapport n ${ }^{\circ}$ 71. Moulouya, Maroc. (2010)

4.H. Lasgaa,T. Boumeaza, A Sbai,Evolution of the coastline of Saidia - Cap Water(Northeastern Morocco). IOSR J. App.Geol.Geop. 3,4 (2015)

5.AEFCS.- Plan Directeur des Aires Protégées du Maroc. Rapport inédit, Administration des Eaux et Forêts et de la Conservation des Sols-BCEOM/SECA-ISR-EPHE.(1996)

6. MedWetCoast-Maroc. La flore de l'embouchure de la Moulouya. Rapp. Inéd.proj.PNUE.Secr. Etat.Envir.(2003)

7. Projet FEM/Banque mondiale (GIZC P121271).Gestion Intégrée des Zones Côtières/Côtes Méditerranéennesrégion de l'Oriental"(2012)

8. M. Barbero, A.Benabid, P.Quezel, S.Rivas Martinez, A.Santos, Contribution à l'étude des Acacio-Arganietalia du Maroc sud occidental. Documentsphyotosociologiques, nov.ser, Camerino, 6(1982)

9. A.Benabid, Flore et écosystèmes du Maroc. Ibis Press, Paris, (2000)

10. A.AAFI, M. Sghir Taleb, M. Fechtal, Espèces remarquables de la flore du Maroc; Centre National de la Recherche Forestière, (2002) 
11. P. Queze, M. Gast, " Genévrier », Encyclopédie berbère [En ligne], document G24, mis en ligne le 01 juin 2011, consulté le 25 septembre 2020. URL: http://journals.openedition.org/. (1998)

12.JP. Grime,Plant strategies and vegetation processes. Wiley, New York,(1979)

13. RP .Adams, the junipers of the world: The genus Juniperus. (TraPubl, Vict, BC, 2004)

14. A. Arar, Y.Nouidjem, R. Bounar, S.Tabet, Y.Kouba,Potential Future Changes of the Geographic Range Size of Juniperusphoenicea in Algeria based on Present and Future Climate Change Projections Con. Pro.Ecol, 13, 4 (2020)

15. E.Remke, E.Brouwer, AM.Kooijman, I.Blindow, H.Esselink, JGM.RoelefsEven low to medium nitrogen deposition impacts vegetation of dry, coastal dunes around the Baltic Sea. Environnement Pollution157(2009)

16. H.Marchante, E.Marchante, H.Freitas, Invasion of the Portuguese dune ecosystems by the invasive species Acacia longifolia Andrews Willd: effects at the community level. In: Child LE, Brock JH, Brundu G, Prach K, Pysek P, Wade PM, Williamson M (eds) Plant invasions: ecological threats and management solutions. Backhuys Publications, Leiden, Netherlands(2003)

17. M C.Muñoz-Reinoso, S. Azqueta, I. Redondo Morales, Restoration of Andalusian Coastal Juniper Woodlands, Restoration of Coastal Dunes, Springer Series on Environmental Management (2013) 